\title{
Using infrasound to constrain ash plume rise
}

\author{
Oliver D. Lamb*, Silvio De Angelis and Yan Lavallée
}

\begin{abstract}
Airborne volcanic ash advisories are currently based on analyses of satellite imagery with relatively low temporal resolution, and numerical simulations of atmospheric plume dispersion. These simulations rely on key input parameters such as the maximum height of eruption plumes and the mass eruption rate at the vent, which remain loosely constrained. In this study, we present a proof-of-concept workflow that incorporates the analysis of volcanic infrasound with numerical modelling of volcanic plume rise in a realistic atmosphere. We analyse acoustic infrasound records from two explosions during the 2009 eruption of Mt. Redoubt, USA, that produced plumes reaching heights of 12-14 km. We model the infrasonic radiation at the source under the assumptions of linear acoustic theory and calculate variations in mass ejection velocity at the vent. The estimated eruption velocities serve as the input for numerical models of plume rise. The encouraging results highlight the potential for infrasound measurements to be incorporated into numerical modelling of ash dispersion, and confirm their value for volcano monitoring operations.
\end{abstract}

Keywords: Infrasound, Ash plume, Plume height, Mt. Redoubt, Volcano

\section{Background}

Mt. Redoubt, a dome-building volcano located $170 \mathrm{~km}$ south-west of Anchorage, Alaska, erupted in March 2009 after approximately 20 years of quiescence. On March 15, a small phreatic explosion marked the onset of the eruption. This was followed by 19 eruptive events between March 23 and April 4, of which at least 16 generated ash plumes with heights of 5-18 km (Schneider and Hoblitt 2013), forcing the grounding of aircraft at Anchorage airport. On April 4, the eruption entered a phase of continuous lava extrusion and dome building at the summit before ending in July 2009.

Mt. Redoubt is one of 50 historically active Alaskan volcanoes located on the busy North Pacific and Far East Russia air traffic corridors along which at least 70 aircraft, collectively carrying approximately 10,000 passengers, fly daily. Between 1953 and 2009, 129 encounters of aircraft with volcanic ash clouds have been documented (Guffanti et al. 2010), including an incident at Mt. Redoubt in 1989 (Casadevall 1994). Rapid growth in air traffic has pushed the scientific and engineering community to increase our ability to detect ash clouds (Prata and Tupper 2009) and

\footnotetext{
*Correspondence: o.lamb@liverpool.ac.uk

Department of Earth, Ocean and Ecological Sciences, University of Liverpool, 4 Brownlow Street, L69 3GP Liverpool, UK
}

constrain the melting characteristics of ash (Song et al. 2014) in order to improve the design of jet engines and mitigate risk (e.g. Drexler et al. 2011). Currently, nine Volcanic Ash Advisory Centers (VAAC) are responsible for issuing warnings of airborne volcanic ash. Advisories are based on satellite imagery and numerical models of atmospheric ash dispersion (Mastin et al. 2009). Whilst numerical models can provide accurate forecasts of atmospheric ash dispersion patterns, they rely on precise knowledge of key eruption parameters such as maximum plume height and mass ejection rates at the vent, which remain loosely constrained.

In recent years the use of acoustic infrasound technology has become commonplace at volcano observatories, in particular to detect eruptions in remote locations (e.g. Caplan-Auerbach and McNutt 2003; De Angelis et al. 2012; Petersen and McNutt 2006) and to measure parameters such as mass eruption rates and plume height (Caplan-Auerbach et al. 2010, Ripepe et al. 2013). A number of studies have focused on estimating gas bubble sizes and gas outflux at the vent during Strombolian-type eruptions (Delle Donne and Ripepe 2012; Firstov and Kravchenko 1996; Gerst et al.
定

C 2015 Lamb et al. Open Access This article is distributed under the terms of the Creative Commons Attribution 4.0 International License (http://creativecommons.org/licenses/by/4.0/), which permits unrestricted use, distribution, and reproduction in any medium, provided you give appropriate credit to the original author(s) and the source, provide a link to the Creative Commons license, and indicate if changes were made. 
2013; Johnson 2003; Kremers et al. 2013; Ripepe et al. 1996; Vergniolle and Caplan-Auerbach 2006). In contrast, only a handful of eruptions accompanied by atmospheric injection of vigorous, ash-rich plumes have been investigated to date (e.g. Caplan-Auerbach and McNutt 2010; Fee et al. 2013; Mastin et al. 2013; Matoza and Fee 2014; McNutt et al. 2013; Ripepe et al. 2013).

In this paper we combine analyses of infrasound observations with numerical modeling of volcanic plume rise in a realistic atmosphere in order to characterize airborne ash injection during the 2009 eruption of Mt. Redoubt. Our results are confirmed by estimates of plume height obtained from Doppler radar measurements (Schneider and Hoblitt 2013), satellite imagery (Webley et al. 2013), and further validated by field observations of tephra fall deposits (Wallace et al. 2013).

\section{Data and Methods}

Mt. Redoubt is monitored by the Alaska Volcano Observatory (AVO) with a permanent network of eleven seismometers. In addition, one infrasonic microphone, a Chaparral Physics Model 25V (flat response between $0.1-200 \mathrm{~Hz}$ ), is located $12.2 \mathrm{~km} \mathrm{NNE}$ of the active vent (McNutt et al. 2013). In March 2009, with an eruption considered imminent, AVO deployed a portable radar system (Electronics Corporation MiniMax-250C Doppler radar) on the Kenai Peninsula, $82 \mathrm{~km}$ east of Mt. Redoubt (giving a beamwidth of $2.6 \mathrm{~km}$ ), in order to monitor eventual ash plumes from the volcano (Schneider and Hoblitt 2013). The Doppler radar captured all major explosions at Mt. Redoubt, providing unprecedented, high-resolution, images of the associated plumes. A detailed description of the radar scanning strategy can be found in (Schneider and Hoblitt 2013). All the explosive events during this eruption were also recorded and measured with lowspatial resolution thermal infrared, mid-infrared, and ultraviolet satellite remote sensing data (Webley et al. 2013). In this study we complement this dataset with an analysis of the infrasound record of two explosions during the 2009 eruption of Mt. Redoubt (Fig. 1a, c).

\section{Infrasound source velocity model}

Fluctuations in air pressure recorded at a distance from a volcanic vent are directly related to acoustic power that, in turn, depends on mass outflux at the source (Caplan-Auerbach et al. 2010; Woulff and McGetchin 1976). The relationship between acoustic power and eruptive flux, however, is complicated by uncertainties in the source dynamics. Woulff and McGetchin (1976) introduced, within the framework of linear acoustic theory, relationships between velocity and power for three source types: monopole, dipole, and quadrupole. A monopole source is one in which variations in pressure are due entirely to the rate of change of mass flux, and can be envisioned as an isotropically expanding source. A dipole is often used to describe a directional jet or gas flux that interacts with solid walls. A quadrupole best represents a gas source that generates noise through turbulence, such as a jet engine.

For a source that radiates sound as a hemisphere of radius $r$, the relation between recorded pressure $p$ and acoustic power $\Pi$ is given by:

$$
\Pi=\frac{\pi r^{2} \Delta p^{2}}{\rho_{\text {air }} c}
$$

where $\rho_{\text {air }}$ is air density, $c$ is the speed of sound and $\Delta p$ is the excess pressure. The modeled acoustic power depends strongly on the radiation mechanisms at the source (monopole, dipole, or quadrupole) and is given by one of the following equations:

$$
\begin{aligned}
& \Pi_{m}=K_{m} \frac{4 \pi R^{2} u^{4} \rho_{a t m}}{c} \\
& \Pi_{d}=K_{d} \frac{\pi R^{2} u^{6} \rho_{a t m}}{c^{3}}
\end{aligned}
$$
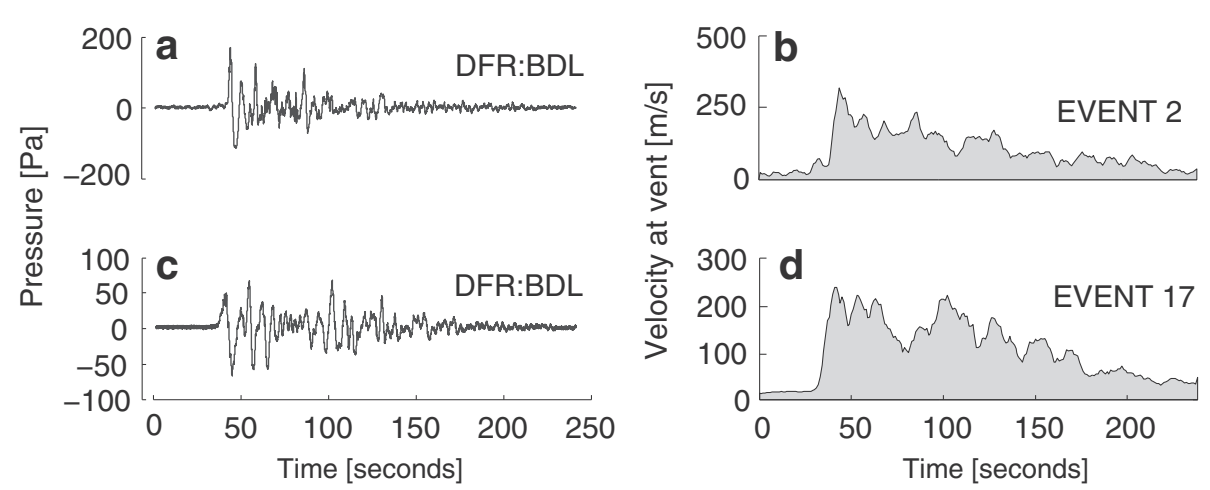

Fig. 1 Infrasound signals and velocity profiles. The recorded infrasound signals, de-trended and high-pass filtered $(0.1 \mathrm{~Hz})$ for removal of very long-period noise/drift (a, c), and calculated mass velocity profiles $(\mathbf{b}, \mathbf{d})$ for event $2(\mathbf{a}, \mathbf{b})$, and event 17 (c, d) 


$$
\Pi_{q}=K_{q} \frac{\pi R^{2} u^{8} \rho_{a t m}}{c^{5}}
$$

where $K_{m}, K_{d}$, and $K_{q}$ are empirically derived constants for specific radiation mechanisms (monopole, dipole, and quadrupole respectively), $R$ is the source radius (i.e. volcanic vent radius), $u$ is the velocity of the material at the source, and $c$ is the speed of sound in air. The value of $K_{m}$ is of the order of 1 , while $K_{d}$ and $K_{q}$ are approximately $10^{-2}$ and $10^{-5}$, respectively (Woulff and McGetchin 1976).

Following Caplan-Auerbach et al. (2010) we favour a dipole source for the explosions at Mt. Redoubt. The presence of conduit walls exerting a force on the erupting gas, the interaction of gas with solid particles within the flow, and the interaction of the infrasound waves with the crater walls around the vent (Bull and Buurman 2013) can be approximated by a dipole radiation model. In our calculation of acoustic power we consider the speed of sound in air to be $320 \mathrm{~m} \mathrm{~s}^{-1}$ (Table 1; McNutt et al. 2013).

For each of the eruptive events considered the infrasound records are pre-filtered between 0.1 and 25 $\mathrm{Hz}$, above the low frequency cut-off of the sensor and in a frequency band that includes the dominant energy of the signal (Fig. 2). Piecewise linear detrending is also applied in order to remove undesireable effects of very long-period instrument drift (Johnson and Miller 2014). We then calculate a 2 -second average of the acoustic power from the infrasound time series using Eq. 1 and invert Eq. 3 to retrieve the timehistory of mass velocity at the vent. The peak value of velocity provides the input for a numerical model of plume rise.

\section{Plume rise model}

We use the PlumeRise model of Woodhouse et al. (2013) to estimate the maximum plume height. This model provides a quantitative, 3-dimensional, description of the rise of volcanic ash columns in a moist and windy atmosphere, and is based on the fluid dynamics of turbulent buoyant plumes. The model includes a description of the thermodynamics of heat transfer between hot pyroclasts and the surrounding magmatic and atmospheric gases. PlumeRise allows assessing the effects of a variable atmosphere on volcanic plume rise and includes a description of the thermodynamics of phase changes of water. The effect of a cross wind on the plume ascent is accounted for, using the entrained formulation of Hewett et al. (1971). For atmospheric conditions, we used soundings measured above Anchorage, $168 \mathrm{~km}$ north-east of Mt. Redoubt, recorded at intervals of 6 or 12 hours (http://weather.uwyo.edu/upperair/sounding. html; last accessed 21/09/2015). For comparison, we also

Table 1 Variables and values used in calculations

\begin{tabular}{|c|c|c|c|}
\hline \multicolumn{4}{|c|}{ Gas velocity modelling } \\
\hline Variable & Definition & Value/units & Reference \\
\hline u & Eruption velocity & (Calculated, see below) & \\
\hline$\Pi$ & Acoustic power & (Not calculated) & \\
\hline$\rho_{\text {air }}$ & Air density & $1.4 \mathrm{~kg} \mathrm{~m}^{-3}$ & \\
\hline c & Speed of sound & $320 \mathrm{~m} \mathrm{~s}^{-1}$ & McNutt et al. (2013) \\
\hline$\tau$ & Source duration & $2 \mathrm{~s}$ & \\
\hline$K_{d}$ & Dipole source empirical constant & $10^{-2}$ & Woulff and McGetchin (1976) \\
\hline$R$ & Volcanic vent radius & $30 \mathrm{~m}$ & Wessels et al. (2013) \\
\hline$r$ & Source-receiver distance & $12.2 \mathrm{~km}$ & McNutt et al. (2013) \\
\hline \multicolumn{4}{|c|}{ Plume modelling } \\
\hline & Parameter & Value/units & Reference \\
\hline & Vent longitude and latitude & $60.48^{\circ},-152.74^{\circ}$ & \\
\hline & Vent elevation & $2400 m$ & \\
\hline & Gas mass fraction & 0.03 & Mastin et al. (2013) \\
\hline & Source temperature & $1173 \mathrm{~K}$ & Mastin et al. (2013) \\
\hline & Solid pyroclastic density & $1200 \mathrm{~kg} \mathrm{~m}^{-3}$ & Mastin et al. (2013) \\
\hline & No-wind train coefficient & 0.09 & Woodhouse et al. (2013) \\
\hline & Wind entrainment coefficient & 0.9 & Woodhouse et al. (2013) \\
\hline & Calculated peak eruption velocities & Event 2: $315 \mathrm{~m} \mathrm{~s}^{-1}$ & \\
\hline & & Event $17: 251 \mathrm{~m} \mathrm{~s}^{-1}$ & \\
\hline
\end{tabular}



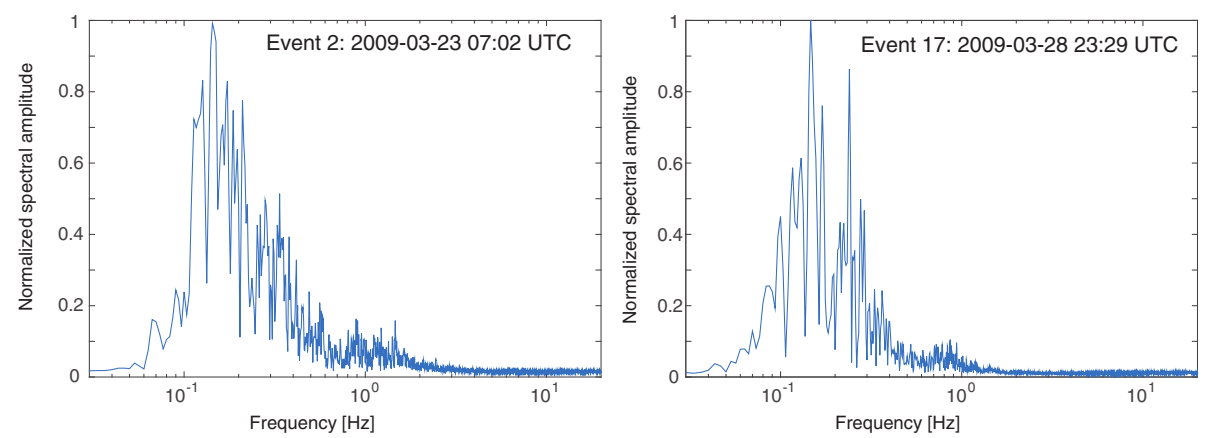

Fig. 2 Frequency spectra of infrasound signals. Frequency spectra of infrasound signals of explosions from Mt. Redoubt on March 23, 2009 07:02 UTC (left) and March 28, 2009 23:29 UTC (right)

estimated the plumes using the US Standard Atmosphere (U.S. Standard Atmosphere, 1976, U.S. Government Printing Office, Washington, D.C., 1976), which is characterized by a piecewise linear temperature profile with height and hydrostatic pressure balance.

For each event analysed, we use the atmospheric sounding measurement taken nearest to the time of the event; additional parameters employed in the plume model along with their sources are listed in Table 1.

\section{Results}

We analysed infrasound signals for two explosive events during the eruption of Mt. Redoubt; events 2 and 17 (following the classification of Bull and Buurman 2013; Fig. 1a, c). Event 2 (7:02 UTC, 23 March) was the first large explosion in the crisis, accompanied by strong seismic and infrasound signals, and a measured plume height of $14 \mathrm{~km}$ (McNutt et al. 2013). From the infrasound signal, we calculated a peak mass velocity of $315 \mathrm{~m} \mathrm{~s}^{-1}$ (Fig. 1b). Event 17 (23:29 UTC, 28 March) was one of the largest explosions (plume height of $12.5 \mathrm{~km}$ ) of a group characterised by short durations (3-4 mins). The calculated peak mass velocity for this event was $251 \mathrm{~m} \mathrm{~s}^{-1}$ (Fig. 1d).

The modelled plumes for events 2 and 17 are presented in Figs. 3 and 4, respectively. Accounting for local atmospheric conditions near the time of the events, including cross-wind (see Section "Plume rise model"), the modelled plumes for event 2 and 17 propagate in the north-east and east directions and reach heights of $13,500 \mathrm{~m}$ and 12,000 $\mathrm{m}$, respectively. These estimates are within $500 \mathrm{~m}$ of those obtained with the Doppler radar (Schneider and Hoblitt 2013). Additionally, the direction of propagation (Figs. 3a, 4a) is consistent with the distribution of tephra-fall deposits measured for these events (Fig. 5; Wallace et al. 2013). Estimated plume distributions calculated using the US Standard Atmosphere remain fixed over the vent and overshoot the measured plume heights in excess of $1500 \mathrm{~m}$.

\section{Discussion}

Numerical models of ash dispersion rely on estimates of initial plume height and mass eruption rates which remain, thus far, poorly constrained. The methods presented here provide a means to infer eruption source parameters from acoustic measurements. Our plume height estimates at Mt. Redoubt expand on previous 1D modelling work by Mastin et al. (2013) for event 5 of the same eruption, who applied a 1D plume rise model assuming a velocity at the vent of $150 \mathrm{~m} \mathrm{~s}^{-1}$. One fundamental difference between our model and previous work by Mastin et al. (2013) is the value used for mass velocity at the vent. They inferred a mass velocity using mapped erupted mass (Wallace et al. 2013) and measured eruption durations, whereas we used a value based on the analysis of infrasound data. Additionally, our model estimates 3D plume propagation with results in excellent agreement with the mapped distribution of tephra-fall deposits (Fig. 5). Mastin et al. (2013) also successfully mapped the distribution of tephra from event 5, using a 3D tephra and ash dispersal model (Ash3d; Schwaiger et al. 2012). Ash3d parameters include the total erupted mass and the total grain size distribution, which may not be accurately constrained until after the end of an eruptive event.

Our model also differs from previous studies at other volcanoes such as Johnson (2007) and Matoza et al. (2009). The former inferred that a monopole source best described pyroclastic explosions from Karymsky volcano, Russia. The explosions from Karymsky were smaller in time (a few seconds) and scale (plume heights $<1 \mathrm{~km}$ ), suggesting a significantly different source mechanism than at Mt. Redoubt. Matoza et al. (2009) contended that sustained eruption noise has its source in large scale turbulence, favouring a quadrupole source. However, the eruptions described by Matoza et al. (2009) generated infrasound signals with durations of hours whereas those at Mt. Redoubt only last for minutes. The vent for the 2009 activity at Mt. Redoubt lies inside a North-facing 

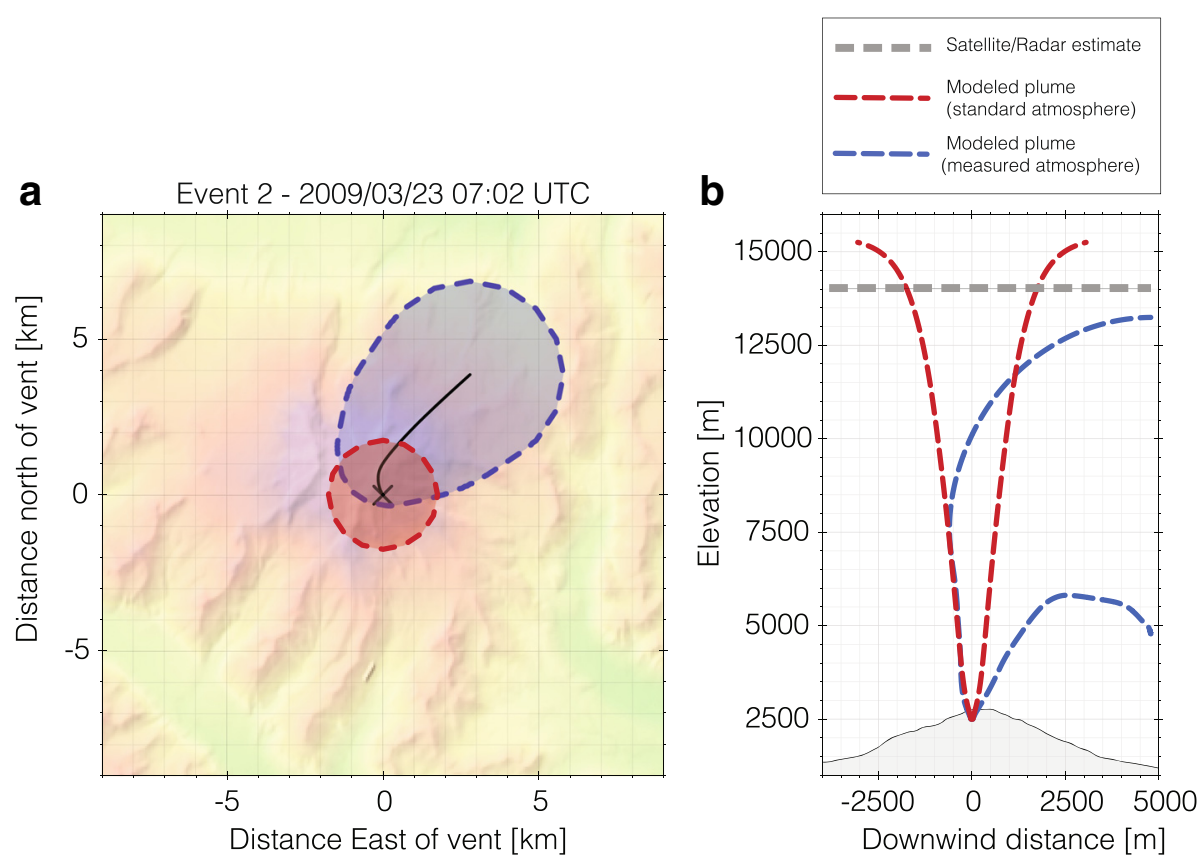

Fig. 3 Estimated plume for event 2. A plan view (a) and cross-sections (b) of the estimated plumes from event 2. Modelled plume heights in standard atmospheric conditions are plotted with red dashed lines, and those with measured atmospheric conditions are plotted with blue dashed lines. The plan view is plotted onto a digital elevation map of the Mt. Redoubt area. The cross-section is plotted along the black line in (a), that is the direction of the prevailing wind during the eruption. Observed plume heights (grey dashed line) were measured with satellite imagery (Webley et al. 2013) and Doppler radar (Schneider and Hoblitt 2013)

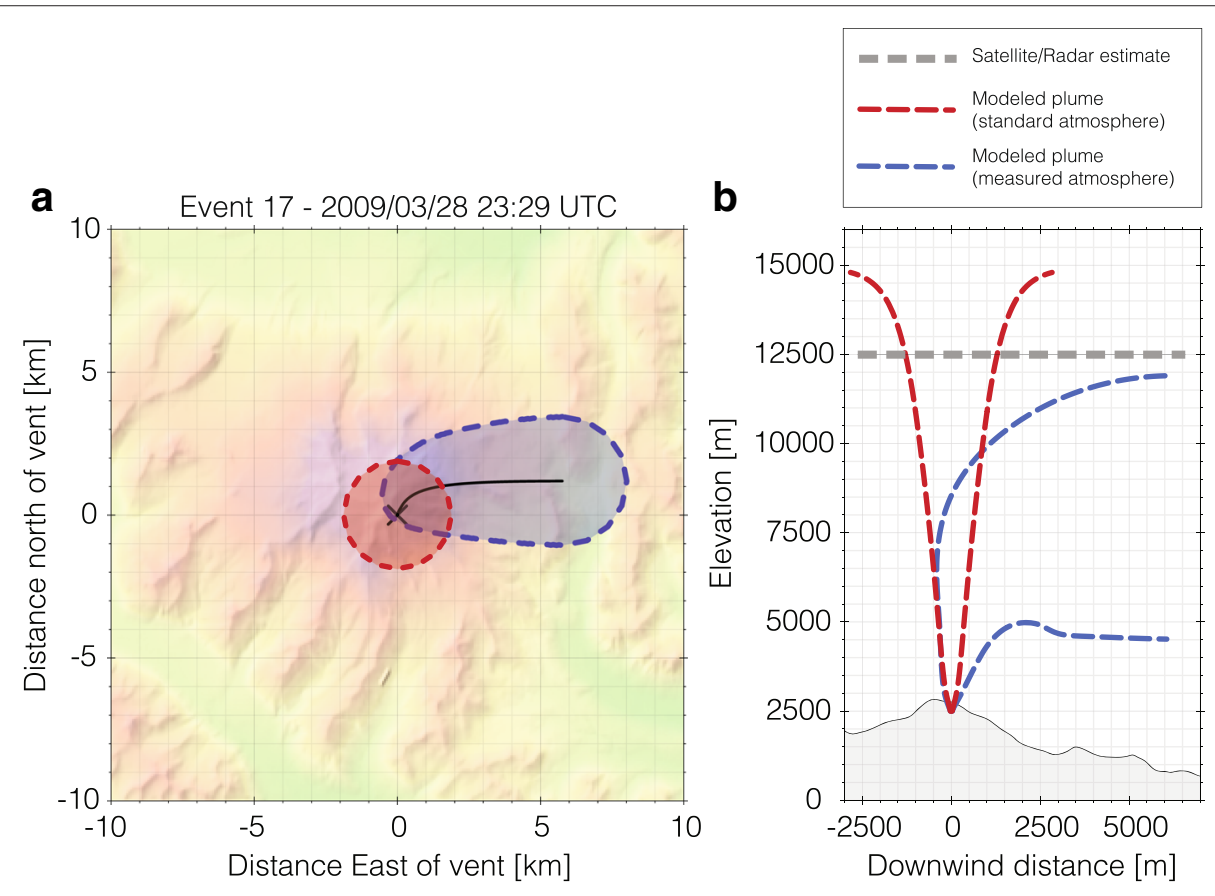

Fig. 4 Estimated plume for event 17. A plan view (a) and cross-sections (b) of the estimated plumes from event 17. Modelled plume heights in standard atmospheric conditions are plotted with red dashed lines, and those with measured atmospheric conditions are plotted with blue dashed lines. The plan view is plotted onto a digital elevation map of the Mt. Redoubt area. The cross-section is plotted along the black line in (a), that is the direction of the prevailing wind during the eruption. Observed plume heights (grey dashed line) were measured with satellite imagery (Webley et al. 2013) and Doppler radar (Schneider and Hoblitt 2013) 


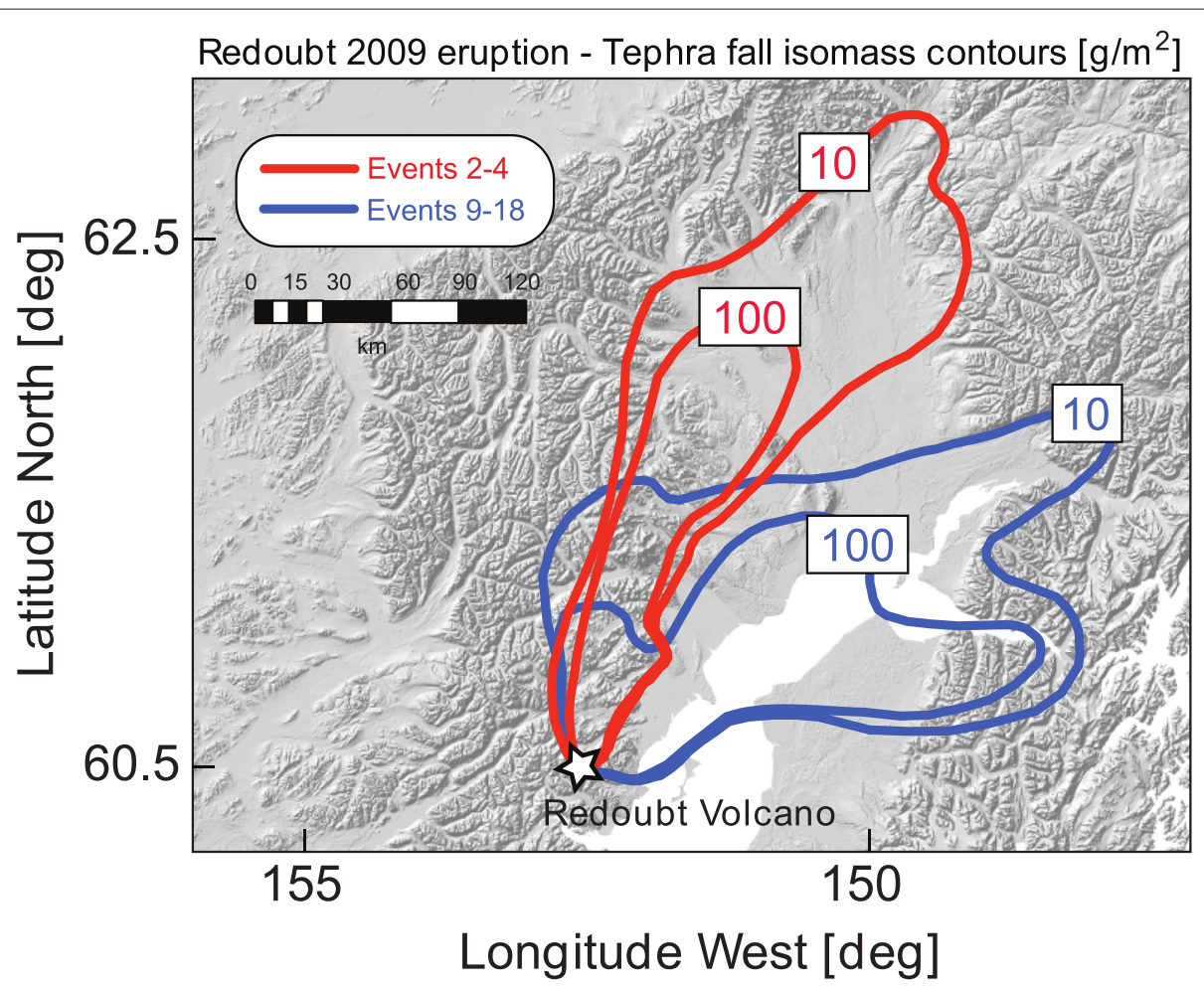

Fig. 5 Isomass contour map. Regional map of the Cook Inlet area, Alaska, showing the distribution of tephra-fall deposits of the 2009 eruption of Mt. Redoubt. Contours show isomass in $\mathrm{g} \mathrm{m}^{-2}$. Modified with permission from Fig. 1 of Wallace et al. (2013); digital contour data available from Schaefer and Wallace (2012)

collapse scar (Bull and Buurman 2013) which causes infrasound waves to interact with the wall around the vent during eruptions. For this reason a dipole source was deemed the most appropriate approximation for our calculations. Infrasound waveform inversion at Tunguruhua volcano, Ecuador, suggested a dipole source to explain the directivity of the acoustic wavefield (Kim et al. 2012).

One notable feature of the infrasound waveforms recorded at Mt. Redoubt in 2009, are their unusually high amplitudes and relatively short rise times of the initial pulse. Whilst these observations support an explosion source mechanism rather than sustained jetting, they also pose questions on the nature of the flow at the vent. For example, for one event (McNutt et al. 2013) showed clipped waveforms with a peak pressure of $173 \mathrm{~Pa}$ and estimated a full-scale pressure of $244 \mathrm{~Pa}$ at the DFR site (corresponding to $>3000$ $\mathrm{Pa}$ at the vent). Such high pressures may imply transonic to supersonic flow conditions at the vent, which would make equations (1-4) not applicable. A non-linear formulation should be considered instead (Marchetti et al. 2013). For instance, employing the RankineHugoniot equations for 1D shock wave theory (e.g., Marchetti et al. 2013) and acoustic pressures between 50-200 $\mathrm{Pa}$ (i.e. within a range compatible with values measured at Mt. Redoubt), would result in velocities at the vent in excess of $1000 \mathrm{~m} \mathrm{~s}^{-1}$. However, such high values are not supported by measurements of plume ascent at Mt. Redoubt using Doppler radar (see Fig. 6 in Schneider and Hoblitt 2013). Alternatively, McNutt et al. (2013) suggested that a highly directional flow may provide an explanation for the unusually high infrasound pressures. Furthermore, in the absence of clear observational evidence of supersonic flow, we assume that non-linear dynamics may be restricted to the near-vent region, and consider that the equations of linear acoustics represent a suitable first-order approximation for the purpose of our investigation.

Our calculations are dependent on the assumption that the infrasound source is best described by a pure dipole. To test this assumption, we repeated our workflow using monopole and quadrupole sources instead. The peak velocities for events $2\left(107\right.$ and $\left.620 \mathrm{~m} \mathrm{~s}^{-1}\right)$ and 17 (65 and $486 \mathrm{~m} \mathrm{~s}^{-1}$ ) using monopole and quadrupole sources are too low or high when compared with values estimated from field observations (e.g. Doppler radar). We acknowledge that the ideal strategy to constrain eruption velocities would be inverting for a multipole source model where monopole, dipole, and quadrupole mechanisms contribute to the radiated acoustic wavefield. Kim et al. (2012) recently proposed a waveform inversion method that represents volcano acoustic sources as 
the combination of multipole terms (i.e. monopole and dipole) and employs analytical Green's functions in a halfspace to model atmospheric sound propagation. Waveform inversion would allow an accurate estimate of time history of mass outflow at the vent and the systems of forces active at the source. However, this type of inversion requires data from multiple sensors, which were not available during the 2009 eruption at Mt. Redoubt. The most significant limitation of models used to characterise the propagation of volcanic infrasound is the use of equations $(2,3,4)$ that are based on simplified Green's functions for a homogenous and isotropic free space. Calculations based on these relations rely on the implicit assumption that wave amplitude decays as an inverse function of distance from source. In this and previous studies, the effects of variable atmosphere, vent geometry, and the local topography on the propagation of infrasound are neglected. Numerical techniques such as finite-difference time-domain can be employed due to their ability to handle complicated phenomena in infrasound propagation, thus allowing inclusion of the effects of topography (Lacanna and Ripepe 2013; Lacanna et al. 2014; Kim et al. 2015).

Plume heights of the events in 2009 were assessed using satellite imagery (Webley et al. 2013) and Doppler radar measurements (Schneider and Hoblitt 2013). Airborne ash was detected by satellites some time after each event. By tracking cloud top temperatures, Webley et al. (2013) were able to estimate plume heights. Their estimates generally fall below measured heights from radar and our estimates. As these measurements were taken some time after the eruptive event, the ash cloud had undoubtedly begun to disperse and cool, leading to apparently lower cloudtop heights. Our estimates fall close to Doppler radar measurements (Schneider and Hoblitt 2013), demonstrating the strength of the PlumeRise model used. In our calculations, we used parameters calculated a-posteriori for each of the events (Table 1). If the proposed methodology is to be used for near real-time assessment of eruptive plumes during future volcanic crises, a number of parameters (e.g. vent radius, gas mass fraction, source temperature, pyroclast density) will need to be estimated based on previous eruptions.

At other volcanoes, eruptive plume heights have been estimated using other geophysical methods. Using data from Kasatochi and Augustine volcanoes, Alaska, Prejean and Brodsky (2011) demonstrated how the amplitude of explosion-sourced seismicity can be related to the mass ejection rate via force-balance equations. However, the method is limited to using a range of ejection rates and requires clear, noise-free signals from multiple stations located around the eruptive centre. Additionally, due to strong attenuation effects, the method is limited by the size of the explosion and the proximity of the seismometers. In Iceland, real-time GPS and tiltmeter measurements were demonstrated to correlate with plume heights during the 2011 eruption at Grímsvötn (Hreinsdóttir et al. 2014). Again, this method is limited by requiring instruments located close $(<10 \mathrm{~km})$ to the eruptive centre as deformation signals can degrade quickly with distance from the pressure source. At present, there is no methodology that provides alone a consistent solution to the problem of estimating mass eruption velocities, or ash plume heights. A multi-parameter, integrated approach should be employed to better constrain eruption dynamics.

A number of simplifying assumptions in our approach mean that we cannot fully replicate the complexity of a natural atmospheric system. However, a workflow based on this relatively simple proof-of-concept would require low computational resources, and results could be available in near real-time. The method proposed here requires few parameters to provide a rapid estimate of ash plume height. Furthermore, recent developments in both infrasound technology and numerical modelling mean that waveform inversion for more complex source mechanisms along with the use of more realistic Green's functions may soon be commonplace. We surmise that acoustic infrasound holds potential to provide accurate near-real time estimates of eruption source parameters such as mass flux rates and maximum plume height required in risk mitigation strategies.

\section{Conclusions}

Infrasound can provide detailed constraints on the timing, duration, and relative intensity of local and remote explosive volcanism, and can be used for early eruption warning. For the aviation industry, a timely issuing of airborne volcanic ash warnings is vital to avoid encounters between aircraft and ash clouds. Whilst numerical models can provide detailed forecasts of atmospheric ash dispersion patterns, they rely on accurate knowledge of key parameters such as initial plume height and mass eruption rates, which remain loosely constrained.

In this study we have presented a proof-of-concept which incorporates the analysis of infrasound data recorded during two explosive events during the 2009 eruption at Mt. Redoubt, USA. Using simple analytical models that describe infrasound radiation at the vent, we have calculated the flux of material ejected from the volcanic vent during each event. The flux measurements were then incorporated into an ash plume rise model, to calculate the maximum height of the eruptive column, and assess its atmospheric dispersal. By comparing the results of our calculations to Doppler radar and satellite measurements, we demonstrated the potential of this and similar methods to obtain accurate estimates of plume heights within seconds of a volcanic explosion. 
The main implication of our results is that key eruption source parameters can be quickly and accurately quantified. Incorporation of infrasound based eruption source parameters into ash transport modelling workflows holds the potential for more efficient forecasts of volcanic ash cloud dispersion.

\section{Competing interests}

The authors declare that they have no competing interests.

\section{Authors' contributions}

ODL carried out the calculation and analysis, and drafted the manuscript. SA participated in the calculation, and helped to draft the manuscript. YL participated in the design of the study and helped to draft the manuscript. All authors read and approved the final manuscript.

\section{Acknowledgements}

We acknowledge the European Research Council for the Starting Grants on 'Strain Localisation in Magmas' (SLiM, No. 306488). The authors also thank Yousif Al-Sharhan for starting this project during his undergraduate studies. The authors are indebted to colleagues of the Alaska Volcano Observatory, including the U.S. Geological Survey, Alaska Division of Geological and Geophysical Surveys, and the University of Alaska Fairbanks for the combined efforts put into the monitoring and eruption response. Permission to use the infrasound data used in this study was granted by the Alaska Volcano Observatory. Finally, we wish to thank Benoit Taisne, an anonymous reviewer, and the associate editor, Chris Newhall, for their comments which greatly improved the manuscript.

Received: 14 July 2015 Accepted: 3 November 2015 Published online: 19 November 2015

\section{References}

Bull KF, Buurman H (2013) An overview of the 2009 eruption of Redoubt Volcano, Alaska. J Volcanol Geotherm Res 259:2-15. doi:10.1016/ j.jvolgeores.2012.06.024

Caplan-Auerbach J, McNutt SR (2003) New insights into the 1999 eruption of Shishaldin volcano, Alaska, based on acoustic data. Bull Volcanol 65(6):405-417

Caplan-Auerbach J, Bellesiles A, Fernandes JK (2010) Estimates of eruption velocity and plume height from infrasonic recordings of the 2006 eruption of Augustine Volcano, Alaska. J Volcanol Geotherm Res 189(1-2):12-18

Casadevall TJ (1994) The 1989-1990 eruption of Redoubt Volcano, Alaska: impacts on aircraft operations. J Volcanol Geotherm Res 62:301-316. doi:10.1016/0377-0273(94)90038-8

De Angelis S, Fee D, Haney M, Schneider D (2012) Detecting hidden volcanic explosions from Mt. Cleveland Volcano, Alaska with infrasound and ground-coupled airwaves. Geophys Res Lett 39:L21312. doi:10.1029/ 2012GL053635

Delle Donne D, Ripepe M (2012) High-frame rate thermal imagery of Strombolian explosions: Implications for explosive and infrasonic source dynamics. J Geophys Res 117:09206. doi:10.1029/2011JB008987

Drexler JM, Gledhill AD, Shinoda K, Vasiliev AL, Reddy KM, Sampath S, Padture NP (2011) Jet engine coatings for resisting volcanic ash damage. Adv Mater 23:2419-2424. doi:10.1002/adma.201004783

Fee D, Matoza RS, Gee KL, Neilsen TB, Ogden DE (2013) Infrasonic crackle and supersonic jet noise from the eruption of Nabro Volcano, Eritrea. Geophys Res Lett 40:4199-4203. doi:10.1002/grl.50827

Firstov P, Kravchenko Ns (1996) Estimation of the amount of explosive gas released in volcanic eruptions using air waves. Volcanol Seismol 17:547-560

Gerst A, Hort M, Aster RC, Johnson JB, Kyle PR (2013) The first second of volcanic eruptions from the Erebus volcano lava lake, Antarctica - Energies, pressures, seismology, and infrasound. J Geophys Res Solid Earth 118:3318-3340. doi:10.1002/jgrb.50234

Guffanti M, Casadevall TJ, Budding K (2010) Encounters of Aircraft with Volcanic Ash Clouds: A Compilation of Known Incidents, 1953 - 2009. US Geol Surv Data Ser 545 1:1-12
Hewett Ta, Fay Ja, Hoult DP (1971) Laboratory experiments of smokestack plumes in a stable atmosphere. Atmos Environ (1967) 5(9):767-789

Hreinsdóttir S, Sigmundsson F, Roberts MJ, Björnsson H, Grapenthin R, Arason P, Árnadóttir T, Hólmjárn J, Geirsson H, Bennett RA, Gudmundsson MT, Oddsson B, Ófeigsson BG, Villemin T, Jónsson T, Sturkell E, Höskuldsson A, Larsen G, Thordarson T, Óladóttir BA (2014) Volcanic plume height correlated with magma- pressure change at Grímsvötn Volcano, Iceland. Nat Geosci 7(12):1-5. doi:10.1038/ngeo2044

Johnson, JB (2003) Generation and propagation of infrasonic airwaves from volcanic explosions. J Volcanol Geotherm Res 121(1-2):1-14

Johnson JB (2007) On the relation between infrasound, seismicity, and small pyroclastic explosions at Karymsky Volcano. J Geophys Res 112(B8):08203. doi:10.1029/2006JB004654

Johnson JB, Miller AJC (2014) Application of the Monopole Source to Quantify Explosive Flux during Vulcanian Explosions at Sakurajima Volcano (Japan) Seismol Res Lett 85(6):1163-1176. doi:10.1785/0220140058

Kim K, Fee D, Yokoo A, Lees JM (2015) Acoustic source inversion to estimate volume flux from volcanic explosions. Geophys Res Lett 42(13):5243-5249. doi:10.1002/2015GL064466

Kim K, Lees JM, Ruiz M (2012) Acoustic multipole source model for volcanic explosions and inversion for source parameters. Geophys I Int 191:1192-1204. doi:10.1111/j.1365-246X.2012.05696.x

Kremers S, Wassermann J, Meier K, Pelties C, van Driel M, Vasseur J, Hort M (2013) Inverting the source mechanism of Strombolian explosions at Mt. Yasur, Vanuatu, using a multi-parameter dataset. J Volcanol Geotherm Res 262:104-122. doi:10.1016/j.jvolgeores.2013.06.007

Lacanna G, Ichihara M, Iwakuni M, Takeo M, Iguchi M, Ripepe M (2014) Influence of atmospheric structure and topography on infrasonic wave propagation. J Geophys Res Solid Earth 119(4):2988-3005. doi:10.1002/2013JB010827

Lacanna G, Ripepe M (2013) Influence of near-source volcano topography on the acoustic wavefield and implication for source modeling. J Volcanol Geotherm Res 250:9-18. doi:10.1016/j.jvolgeores.2012.10.005

Marchetti E, Ripepe M, Delle Donne D, Genco R, Finizola A, Garaebiti E (2013) Blast waves from violent explosive activity at Yasur Volcano, Vanuatu. Geophys Res Lett 40(22):5838-5843. doi:10.1002/2013GL057900

Mastin LG, Guffanti M, Servranckx R, Webley P, Barsotti S, Dean K, Durant A, Ewert JW, Neri A, Rose WI, Schneider D, Siebert L, Stunder B, Swanson G, Tupper A, Volentik A, Waythomas CF (2009) A multidisciplinary effort to assign realistic source parameters to models of volcanic ash-cloud transport and dispersion during eruptions. J Volcanol Geotherm Res 186(1-2):10-21

Mastin LG, Schwaiger H, Schneider DJ, Wallace KL, Schaefer J, Denlinger RP (2013) Injection, transport, and deposition of tephra during event 5 at Redoubt Volcano, 23 March, 2009. J Volcanol Geotherm Res 259:201-213

Matoza RS, Fee D (2014) Infrasonic component of volcano-seismic eruption tremor. Geophys Res Lett 41:1964-1970. doi:10.1002/2014GL059301.Received

Matoza RS, Fee D, Garcés MA, Seiner JM, Ramón PA, Hedlin MAH (2009) Infrasonic jet noise from volcanic eruptions. Geophys Res Lett 36(8):08303. doi:10.1029/2008GL036486

McNutt SR, Thompson G, West ME, Fee D, Stihler S, Clark E (2013) Local seismic and infrasound observations of the 2009 explosive eruptions of Redoubt Volcano, Alaska. J Volcanol Geotherm Res 259:63-76

Petersen T, McNutt SR (2006) Seismo-acoustic signals associated with degassing explosions recorded at Shishaldin Volcano, Alaska, 2003-2004. Bull Volcanol 69(5):527-536

Prata AJ, Tupper A (2009) Aviation hazards from volcanoes: The state of the science. Nat Hazards 51:239-244. doi:10.1007/s11069-009-9415-y

Prejean SG, Brodsky EE (2011) Volcanic plume height measured by seismic waves based on a mechanical model. J Geophys Res 116:01306. doi:10.1029/2010JB007620

Ripepe M, Bonadonna C, Folch A, Delle Donne D, Lacanna G, Marchetti E, Höskuldsson A (2013) Ash-plume dynamics and eruption source parameters by infrasound and thermal imagery: The 2010 Eyjafjallajökull eruption. Earth Planet Sci Lett 366:112-121

Ripepe M, Poggi P, Braun T, Gordeev E (1996) Infrasonic waves and volcanic tremor at Stromboli. Geophys Res Lett 23(2):181-184

Schaefer JR, Wallace KL (2012) Ash fall contour map of the 2009 eruption of Redoubt Volcano, Alaska: Digital shapefiles of contours and sample locations. Alaska Div Geol Geophys Surv Misc Publication 143. doi:10.14509/23463 
Schneider DJ, Hoblitt RP (2013) Doppler weather radar observations of the 2009 eruption of Redoubt Volcano, Alaska. J Volcanol Geotherm Res 259:133-144

Schwaiger HF, Denlinger RP, Mastin LG (2012) Ash3d: A finite-volume, conservative numerical model for ash transport and tephra deposition. J Geophys Res 117:04204. doi:10.1029/2011JB008968

Song W, Hess K-U, Damby DE, Wadsworth FB, Lavallée Y, Cimarelli C, Dingwell DB (2014) Fusion characteristics of volcanic ash relevant to aviation hazards. Geophys Res Lett 41:2326-2333. doi:10.1002/2013GL058954.Received Vergniolle S, Caplan-Auerbach J (2006) Basaltic thermals and Subplinian plumes: Constraints from acoustic measurements at Shishaldin volcano, Alaska. Bull Volcanol 68(7-8):611-630

Wallace KL, Schaefer JR, Coombs ML (2013) Character, mass, distribution, and origin of tephra-fall deposits from the 2009 eruption of Redoubt Volcano, Alaska-Highlighting the significance of particle aggregation. Journal of Volcanology and Geothermal Research 259:145-169

Webley PW, Lopez TM, Ekstrand AL, Dean KG, Rinkleff P, Dehn J, Cahill CF, Wessels RL, Bailey JE, Izbekov P, Worden A (2013) Remote observations of eruptive clouds and surface thermal activity during the 2009 eruption of Redoubt volcano. J Volcanol Geotherm Res 259:185-200

Wessels RL, Vaughan RG, Patrick MR, Coombs ML (2013) High-resolution satellite and airborne thermal infrared imaging of precursory unrest and 2009 eruption at Redoubt Volcano, Alaska. J Volcanol Geotherm Res 259:248-269. doi:j.jvolgeores.2012.04.014

Woodhouse MJ, Hogg AJ, Phillips JC, Sparks RSJ (2013) Interaction between volcanic plumes and wind during the 2010 Eyjafjallajökull eruption, Iceland. J Geophys Res Solid Earth 118(1):92-109. doi:10.1029/2012JB009592

Woulff G, McGetchin TR (1976) Acoustic Noise from Volcanoes: Theory and Experiment. Geophys J Int 45(3):601-616

\section{Submit your manuscript to a SpringerOpen ${ }^{\circ}$ journal and benefit from:}

- Convenient online submission

- Rigorous peer review

- Immediate publication on acceptance

- Open access: articles freely available online

- High visibility within the field

- Retaining the copyright to your article 